\title{
Peningkatan Hasil Belajar IPA Melalui Penerapan Pendekatan Keterampilan Proses di SMPN Kecamatan Belitang Madang Raya
}

\author{
Wahid Gunarto \\ SMP Negeri 3 Belitang Madang Raya \\ *E-mail: wahid_gunarto@yahoo.co.id
}

\begin{abstract}
Abstrak
Penelitian ini dilatarbelakangi kurangnya minat dan perhatian siswa tarhadap mata pelajaran IPA, sehingga hasil belajar siswa belum tuntas secara klasikal. Tujuan penelitian ini adalah mengetahui peningkatan hasil belajar IPA khususnya materi pembelajaran Fisika melalui menerapkan pendekatan pembelajaran keterampilan proses. Jenis penelitian ini adalah penelitian tindakan kelas (PTK) yang dilaksanakan mulai dari pra siklus, siklus I dan siklus II. Teknik pengumpulan data dalam penelitian ini adalah teknik observasi dan teknik tes. Adapun analisis data yang digunakan adalah teknik deskripsi dari data observasi dan tes. Dari analisis data didapatkan hasil penelitian dari pra siklus sampai ke siklus II yaitu persiapan guru mengalami peningkatan dari $74,0 \%$ pada pra siklus, $81,0 \%$ pada siklus I dan $96,3 \%$ pada siklsu II. Aktivitas guru mengalami peningkatan dari 50,0\% pada pra siklus, $77,1 \%$ pada siklus I dan $98,0 \%$ pada siklus II. Hasil belajar siswa mengalami peningkatan dari ketuntasan $67,0 \%$ pada pra siklus, $77,8 \%$ pada siklus I dan 96,3\% pada siklus II. Sedangkan aktivitas siswa mengalami peningkatan dari kriteria cukup, baik dan sangat baik. Dengan hasil tersebut maka peneliti berkesimpulan bahwa penerapan pendekatan pembelajaran keterampilan proses dapat meningkatkan hasil belajar siswa pada materi pembelajaran Listrik Statis.
\end{abstract}

Kata kunci: Pendekatan Pembelajaran Keterampilan Proses, Hasil Belajar, dan Listrik Statis.

\section{PENDAHULUAN}

Pendidikan merupakan usaha sadar yang dilakukan agar siswa dapat mengembangkan potensi dirinya. Sebagaimana terdapat dalam pasal 1 ayat (1) Undang - Undang Sistem Pendidikan Nasional Peraturan Pemerintah Nomor 20 Tahun 2003 tentang Standar Nasional Pendidikan. Menurut Hamalik (2010) pendidikan adalah suatu proses dalam rangka mempengaruhi siswa supaya mampu menyesuaikan diri sebaik mungkin dengan lingkungannya. Dengan demikian akan menimbulkan perubahan dalam dirinya.

Sekolah sebagai suatu lembaga pendidikan formal merencanakan dan melaksanakan kegiatan belajar. Proses belajar memiliki berbagai bentuk hasil belajar seperti pengetahuan, pemahaman, sikap, dan tingkah laku, kecakapan, keterampilan dan kemampuan, serta perubahan aspek-aspek yang ada pada individu. Hal ini sesuai dengan pendapat yang disampaikan oleh Rohani (2004) menjelaskan bahwa Belajar adalah proses perubahan tingkah laku berkat pengalaman dan latihan. Tanpa pengalaman dan latihan sangat sedikit proses belajar dapat berlangsung. Pengalaman adalah suatu interaksi antara individu dengan lingkungan pengamatannya, dalam interaksi itulah individu belajar, ia memperoleh pengertian, sikap, keterampilan, dan sebagainya.

Salah satu upaya memperbaiki kualitas pembelajaran di dalam kelas yaitu semula berpusat pada guru (teacher-centered) beralih berpusat pada siswa (student centered). Oleh karena itu guru harus dapat memilih metode, model atau pendekatan pembelajaran yang tepat agar situasi pembelajaran lebih kondusif untuk mencapai tujuan yang diharapkan. Hal ini di alami pada kegiatan pembelajaran IPA di SMP Negeri 3 Belitang Madang Raya. Proses pembelajaran IPA diharapkan menghasilkan perubahan-perubahan dalam bidang pengetahuan dan pemahaman nilai, sikap dan keterampilan. Pelaksanaan proses pembelajaran IPA yang benar mencakup 4 komponen : (1) IPA sebagai produk, (2) IPA sebagai proses, (3) IPA sebagai sikap dan, (4) IPA sebagai teknologi. Firdaus, T., \& Sinensis, A. R. (2017) menyatakan bahwa Pendidikan IPA menekankan pada pemberian pengalaman langsung untuk mengembangkan kompetensi agar peserta didik mampu menjelajahi dan memahami alam sekitar 
secara ilmiah.

Berdasarkan hasil observasi di SMP Negeri 3 Madang Raya didapatkan bahwa hasil belajar IPA khususnya mata pelajaran IPA masih rendah. Hal ini di sebabkan kurangnya minat dan perhatian siswa terhadap pembelajaran yang penyampaian materi pembelajarannya kurang menarik di antaranya mata pelajaran IPA pada materi pembelajaran Listrik Statis. Dalam pembelajaran IPA selama ini, guru menjelaskan materi pembelajaran dengan cara ceramah dan memberikan soal-soal untuk diselesaikan oleh siswa. Hal ini membuat siswa kurang berpartisipasi aktif untuk mengikuti pembelajaran IPA dan dapat dilihat dari adanya siswa yang kurang memperhatikan pada saat guru menyampaikan materi pembelajaran. Selain itu siswa kurang aktif dalam pembelajaran mengikuti setiap langkah pembelajaran dalam memahami konsep IPA. Langkah dalam pembelajaran hendaknya membantu siswa dalam memahami konsep IPA secara sistematis.

Salah satu cara yang dapat digunakan untuk memenuhi tuntutan dan mengurangi masalah yaitu dengan cara menerapkan pendekatan keterampilan proses pada pembelajaran IPA pada salah satu SMP Negeri di Kecamatan Belitang Madang Raya. Pendekatan keterampilan proses merupakan pendekatan pembelajaran yang mengarah pada pengembangan kemampuan dasar berupa mental fisik, dan sosial untuk menemukan fakta dan konsep. Pendekatan keterampilan proses juga dapat digunakan untuk mengembangkan sikap siswa melalui proses pembelajaran yang aktif dan kreatif sehingga mampu menumbuhkan sejumlah keterampilan tertentu pada diri siswa. Dengan pendekatan keterampilan proses diharapkan siswa akan menemukan sendiri fakta dan konsep tentang Listrik Statis serta menumbuhkan sikap yang dituntut dalam tujuan pembelajaran. Bentuk dan pelaksanaan dari pendekatan keterampilan proses di antaranya mengamati, mengklasifikasikan, mengkomunikasikan, mengukur, memprediksi dan menyimpulkan konsep tentang Listrik Statis.

Penerapan pendekatan keterampilan proses pada mata pelajaran IPA akan memberikan kesempatan kepada siswa bekerja dengan ilmu pengetahuan, tidak hanya sekedar menceritakan atau mendengarkan cerita tentang ilmu pengetahuan tetapi siswa diharapkan mampu mengutarakan ide-ide dan merumuskan hipotesis yang telah diperoleh.

\section{METODE}

Penelitian ini dilaksanakan dengan menggunakan jenis Penelitian Tindakan Kelas (PTK). Dalam pelaksanan penelitin ini menggunakan desain penelitian tindakan kelas dengan melalui empat tahapan yaitu seperti yang di rumuskan oleh Hopkins (2014) yaitu perencanaan (planning), Aksi (action), pengamatan (observation), dan refleksi (reflection). Penelitian tindakan kelas ini dilaksanakan pada semester gazal di kelas IX-a SMP Negeri 3 Belitang Madang Raya tahun pembelajaran 2016/2017. Pelaksanaan penelitian ini dimulai dari pra siklus, siklus I dan siklus II. Target yang akan dicapai dalam penelitian ini yaitu $85 \%$ dari jumlah siswa telah tuntas dalam memahami konsep Listrik Statis. Jika hasil penelitian belum mencapai target yang telah ditentukan maka penelitian tindakan kelas ini dapat dilanjutkan ke siklus berikutnya. Dari setiap siklus penelitian dilakukan perbaikan dengan menggunakan hasil refleksi siklus sebelumnya sebagai pertimbangan untuk menentukan langkah pada siklus berikutnya.

Teknik pengumpulan data dalam penelitian ini menggunakan teknik observasi dan tenik tes.

Pengumpulan data menggunakan teknik observasi yaitu untuk mengamati pelaksanaan pembelajaran yang menerapkan pendekatan keterampilan proses. Pengamatan dilakukan untuk mendapatkan data tentang pelaksanaan pembelajaran yang menerapkan pendekatan keterampilan proses pada materi pembelajaran Listrik Statis di kelas IX.

Pengumpulan data menggunakan teknik tes yaitu untuk mendapatkan hasil belajar siswa yang saat pembelajarannya menerapkan pendekatan keterampilan proses pada materi pembelajaran Listrik Statis di kelas IX-a di salah satu SMP Negeri kecamatan Belitang Madang Raya tahun pembelajaran 2016/2017. Instrumen tes tentang Listrik Statis yang digunakan dalam penelitian ini tes berbentuk esai. Tes dilakukan di akhir pembelajaran setelah satu siklus tindakan pembelajaran yang dilakukan dengan 
pendekatan keterampilan proses. Berikut ini adalah bagan siklus penelitian tindakan kelas ini.

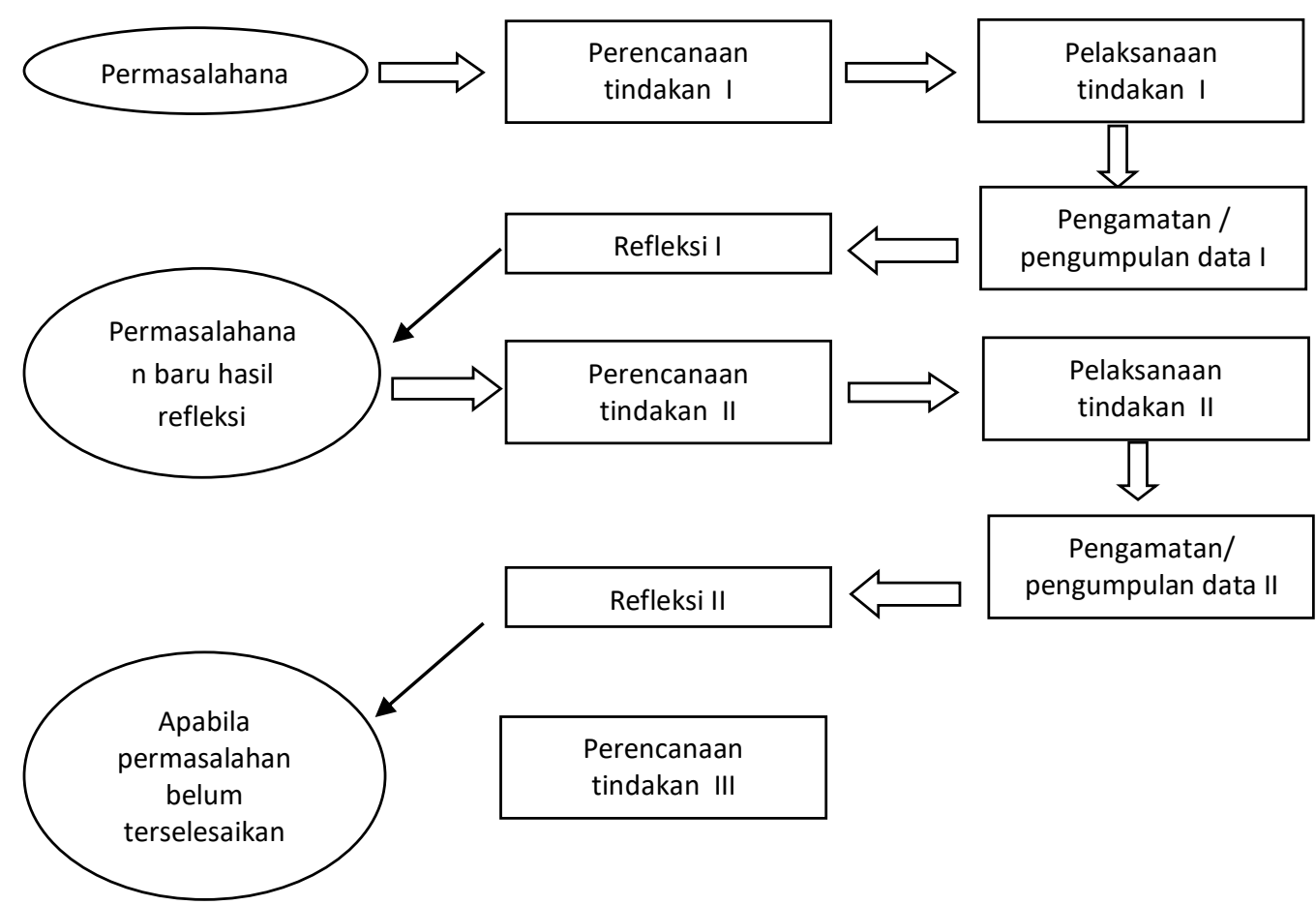

Bagan 1. Siklus Pembelajaran

Sumber: Arikunto (2015)

Proses pengumpulan data observasi dalam penelitian ini dilakukan pada saat pelaksanaan pembelajaran di setiap siklus. Sedangkan pengumpulan data hasil belajar siswa dilakukan pada saat kegiatan pembelajaran telah berakhir setiap satu siklus dilaksanakan. Setiap siklus terdiri dari perencanaan (planning), Aksi (action), pengamatan (observation), dan refleksi (reflection). Proses pembelajaran dan hasil belajar siswa diharapkan mengalami peningkatan. Peningkatan terebut akan dicapai dengan adanya perbaikan pada setiap tahapan dalam setiap siklus pembelajaran.

\section{HASIL DAN PEMBAHASAN}

Penelitian ini diawali dengan melakukkan perencanaan pra siklus dan dilanjutkan membuat perangkat pembelajaran. Mempersiapkan Rencana Pelaksanaan Pembelajaran (RPP), dan instrumen pengumpul observasi dan instrumen tes untuk digunakan dalam pengumplan data penelitian. Instrumen pengumpul data observasi berupa lembar observasi persiapan guru, lembar observasi penerapan pendekatan pembelajaran, dan lembar observasi aktivitas siswa. Selain itu mempersiapkan instrumen tes untuk siswa yang menyatu dengan RPP.

Pelaksanaan pra siklus di awali dengan penerapan pendekatan konvensional saat pembelajaran, kegiatan pembelajaran belum menerapkan pendekatan keterampilan proses. Kegiatan pembelajaran dimulai dengan pendahuluan yaitu melakukan apersepsi dan motivasi tentang Listrik Statis pada sub konsep Atom. Tindakan selanjutnya yaitu menjelaskankan tujuan pembelajaran kepada siswa. Setelah guru menyampaikan tujuan pembelajaran, langkah berikutnya adalah melaksanakan pembelajaran dengan kegiatan inti. Kegiatan inti dalam pembelajaran ini yaitu dimulai dengan menggunakan pendekatan konvensional. Kegiatan inti dimulai dengan cara menjelaskan pokok-pokok materi tentang Listrik Statis pada sub konsep Atom. Siswa memperhatikan penjelasan guru tentang sub konsep Atom. Kemudian siswa memahami sub konsep Atom melalui beberapa sumber belajar, misal buku paket dan beberapa bukur referensi lainya. Langkah selanjutnya yaitu memberikan pengarahan kepada siswa untuk membuat catatan tentang sub konsep Atom.

Kegiatan pembelajaran diakhiri guru bersama siswa menyimpulkan materi tentang sub konsep 
Atom dan guru memberi penguatan materi dengan menjelaskan penerapan sub konsep Atom dalam kehidupan sehari-hari. Kegiatan selanjutnya yaitu memberikan soal tes tentang sub konsep atom pada siswa untuk dikerjakan. Setelah soal selesai dikerjakan siswa diminta untuk mengumpulkan lembar jawaban. Kemudian guru memberi saran pada siswa untuk lebih giat belajar lagi untuk di rumah maupun di sekolah dan mengucapkan salam penutup.

Pengamatan persiapan pembelajaran yang dilakukan oleh guru pada pra siklus diamati oleh observer didapatkan hasil bahwa persiapan pembelajaran guru pada pra siklus yaitu $74 \%$. Aktivitas pembelajaran yang dilakukan oleh guru pada pra siklus diamati oleh observer didapatkan hasil bahwa aktivitas guru saat pembelajaran pada pra siklus yaitu $50 \%$. Aktivitas siswa saat kegiatan pembelajaran pra siklus diamati oleh observer didapatkan hasil bahwa aktivitas siswa mencapai skor rata-rata 8,9 dengan kriteria baik.

Tes penguasaan tentang konsep atom oleh siswa yang terdari dari 6 soal berbentuk essay. Berdasarkan hasil tes tentang sub konsep Atom didapat hasil bahwa dari 27 siswa terdapat 18 siswa yang nilainya sudah mencapai KKM dengan persentase sebesar $67 \%$ dan 9 siswa nilainya belum mencapai KKM dengan persentase sebesar 33\%. Keberhasilan dan kekurangan pra siklus yaitu : 1) Terdapat 9 siswa yang belum tuntas dalam mengikuti pembelajaran. 2) Banyak waktu yang bekum dapat dimanfaatkan dalam pembelajaran terutama pembentukkan kelompok sehingga dapat dikatakan penggunaan waktu dalam pembentukan kelompok belum efesien. 3) Guru belum maksimal dalam memberikan memotivasi pada siswa, kurang berpartisipasinya siswa dalam pembelajaran. Hasil tindakan pada pra siklus secara keseluruhan belum mencapai target, maka penelitian perlu dilajutkan ke siklus I

Rencana siklus I berdasarkan refleksi pra siklus yaitu: 1) Memberikan tambahan motivasi kepada siswa agar lebih konsentrasi dalam mengikuti setiap langkah kegiatan pembelajaran. 2) Menjelaskan kembali langkah-langkah pembelajaran dengan pendekatan yang akan diterapkan yairu pendekatan keterampilan proses, sehingga diharapkan tidak ada siswa yang mengalami kebingungan dalam proses pembelajaran. 3) Memberi penjelasan dan memotivasi siswa untuk tidak malu dalam belajar secara berkelompok. 4) Memotivasi siswa untuk bertanya dan menjawab pertanyaan siswa, dan meminta tiap kelompok belajar untuk membuat pertanyaan secara bergiliran. 5) Memberikan pengarahan tentang kerapian dan benarnya dalam pembuatan laporan.

Tindakan awal pada siklus I yaitu membuat RPP yang menerapkan pendekatan keterampilan proses yaitu dimulai dari : 1. Pendahuluan atau Pemanasan. Kegiatan pendahuluan atau pemanasan tersebut berupa: a) Pengulasan atau pengumpulan bahan yang ada hubungannya dengan sub konsep Sifat Muatan Listrik. b) Kegiatan mengarahkan perhatian siswa dengan mengajukan pertanyaan, pendapat dan saran menunjukkan gambar atau benda lain yang berhubungan dengan sub konsep Sifat Muatan Listrik. 2. Pelaksanaan Proses Belajar Mengajar atau Bagian Inti. Kegiatan proses pembelajaran sub konsep Sifat Muatan Listrik, berupa mengamati, mengklasifikasi, menginteraksikan, meramalkan, mengaplikasikan konsep Sifat Muatan Listrik, merencanakan dan melaksanakan penelitian serta mengkunikasikan hasil yaitu berupa : 1) Menjelaskan sub konsep Sifat Muatan Listrik yaitu dengan peragaan, demonstrasi, gambar, model, bagian yang sesuai dengan keperluan. 2) Merumuskan hasil pengamatan dengan merinci, mengelompokkan atau mengklasifikasikan Sifat Muatan Listrik yang diserap dari kegiatan pengamatan terhadap bahan pelajaran tersebut. Kesimpulan tentang konsep Sifat Muatan Listrik perlu dimanfaatkan atau digunakan. 3) Menafsirkan hasil pengelompokkan itu dengan menunjukkan sifat, hal dan peristiwa atau gejala yang terkandung pada tiap-tiap kelompok dan siswa mencatat hasil dari pengamatan yang telah dilakukan oleh tiap-tiap kelompok. 4) Meramalkan sebab akibat kejadian perihal atau peristiwa Sifat Muatan Listrik. Hasil interpretasi dari pengamatan Sifat Muatan Listrik digunakan untuk meramalkan atau memperkirakan kejadian yang belum diamati atau akan datang. 5) Menerapkan pengetahuan keterampilan sikap yang ditentukan atau diperoleh dari kegiatan sebelumnya pada keadaan atau peristiwa yang baru atau berbeda. Hal ini siswa dapat menjelaskan peristiwa baru dengan menggunakan konsep Sifat Muatan Listrik yang telah dimiliki seperti menuturkan, menjelaskan dan menerangkan. 6) Merencanakan 
penelitian sederhana berupa percobaan Sifat Muatan Listrik untuk menguji kebenaran hipotesis. 7) Mengkomunikasikan hasil kegiatan pada orang lain dengan diskusi untuk mengkomunikasikan proses dan hasil penelitian kepada berbagai pihak yang berkepentingan baik dalam bentuk kata-kata, grafik, bagan maupun tabel secara lisan atau tertulis. 3. Penutup. Setelah melaksanakan proses belajar tersebut, hendaknya guru: 1) Mengkaji ulang kegiatan yang telah dilaksanakan serta merumuskan hasil yang telah diperolehnya. 2) Guru bersama siswa membuat kesimpulan. 3) Mengadakan tes akhir. 4) Memberikan tugas-tugas lain.

Pendekatan keterampilan proses hanyalah merupakan alat bantu pembelajaran, oleh karena itu siswa harus tetap mempelajari konsep listrik statis pada sub konsep Sifat Muatan Listrik dari sumber yang lain. Sumber pembelajaran yang lain dapat beruapa buku paket, buku referensi, dan alat bantu peraga pembelajaran. Siswa memanfaatkan media sebagai sumber pembelajaran, untuk membantu memahami sub konsep Sifat Muatan Listrik melalui media pembelajaran maka siswa dalam kelompok melakukan diskusi.

Pengamatan siklus I dilakukan observer didapatkan hasil bahwa persiapan pembelajaran guru pada siklus I yaitu $81 \%$. Aktivitas pembelajaran yang dilakukan oleh guru pada siklus I diamati oleh observer didapatkan hasil bahwa aktivitas guru saat pembelajaran pada siklus I yaitu $77,1 \%$. Aktivitas siswa saat pembelajaran didapatkan hasil bahwa aktivitas siswa pada siklus I yaitu mencapai skor ratarata 9,1 dengan kriteria baik. Tes penguasaan materi sub konsep Sifat Muatan Listrik diperoleh bahwa dari 27 siswa terdapat 21 siswa sudah mencapai KKM dengan persentase sebesar $77,1 \%$ dan 6 siswa nilainya belum mencapai KKM dengan persentase sebesar 22,1\%.

Adapun keberhasilan yang telah dicapai dalam pembelajaran siklus I adalah sebagai berikut : 1) Terdapat peningkatan persiapan guru. 2) Aktifitas guru mengalami peningkatan. 3) Hasil belajar siswa telah mengalami peningkatan. Adapun kelemahan-kelemahan pada siklus I adalah sebagai berikut : 1) Terdapat 6 peserta didik yang belum tuntas dalam mengikuti pembelajaran. 2) Banyak waktu yang terpakai untuk melakukan pembentukan kelompok sehingga pembentukan kelompok belum efesien.

3) Pendidik kurang memotivasi siswa, posisi duduk siswa saat belajar secara kelompok belum semua saling berhadapan, hal ini berdampak pada kurangnya partisipasi siswa dalam kelompok belajarnya. Hasil tindakan pada siklus I belum mencapai target.

Memperbaiki kelemahan dan mempertahankan keberhasilan pada siklus I, maka pada pelaksanaan siklus II dibuat rencana perbaikan sebagai berikut: 1) Memberikan ketegasan kepada siswa yang terlambat hadir ketika kegiatan pembelajaran akan dimulai. 2) Menjelaskan kembali langkah-langkah pembelajaran, sehingga diharapkan tidak ada siswa yang mengalami kebingungan dalam proses pembelajaran. 3) Memberi penjelasan dan memotivasi siswa untuk tidak malu dalam belajar secara berkelompok. 4) Memotivasi siswa untuk bertanya dan menjawab pertanyaan guru, dan meminta tiap kelompok belajar untuk membuat pertanyaan secara bergiliran. 5) Memberikan pengarahan tentang kerapian dan benarnya dalam pembuatan laporan.

Hasil refleksi pada pembelajaran siklus I menunjukkan hasil penelitian belum mencapai target maka penelitian harus dilanjutkan pada siklus II. Refleksi dari siklus I mengharuskan diadakan perbaikan pada siklus II. Perencanaan tindakan pada siklus II yaitu membuat RPP yang memuat kegiatan pembelajaran

Tindakan awal pada siklus II yaitu membuat RPP yang menerapkan pendekatan keterampilan proses seperti pada siklus I. Pada siklus II konsep yang dipelajari yaitu Hukum Coulomb. Tindakan sikuls II dimulai dari 1. Pendahuluan atau Pemanasan. a) Mengumpulkan bahan yang ada hubungannya dengan sub konsep Hukum Coulomb. b) Kegiatan mengarahkan perhatian siswa dengan mengajukan pertanyaan, pendapat dan saran menunjukkan gambar atau benda lain yang berhubungan dengan sub Hukum Coulomb. 2. Pelaksanaan Proses Belajar Mengajar atau Bagian Inti. Kegiatan proses pembelajaran sub konsep Hukum Colulomb yaitu mengaplikasikan konsep dan melaksanakan penelitian serta mengkunikasikan hasil yaitu berupa : 1) Menjelaskan sub konsep Hukum Coulomb yaitu dengan peragaan, demonstrasi, gambar, model, bagian yang sesuai dengan 
keperluan. 2) Merumuskan hasil pengamatan dengan merinci, mengelompokkan atau mengklasifikasikan Hukum Coulomb yang diserap dari kegiatan pengamatan terhadap bahan pelajaran tersebut. Kesimpulan tentang konsep Hukum Coulomb perlu dimanfaatkan atau digunakan. 3) Menafsirkan hasil pengelompokkan itu dengan menunjukkan sifat, hal dan peristiwa atau gejala yang terkandung pada tiap-tiap kelompok dan siswa mencatat hasil dari pengamatan yang telah dilakukan oleh tiap-tiap kelompok. 4) Meramalkan sebab akibat kejadian perihal atau peristiwa Hukum Coulomb. Hasil interpretasi dari pengamatan Hukum Coulomb digunakan untuk meramalkan atau memperkirakan kejadian yang belum diamati atau akan datang. 5) Menerapkan pengetahuan keterampilan sikap yang ditentukan atau diperoleh dari kegiatan sebelumnya pada keadaan atau peristiwa yang baru atau berbeda. Hal ini siswa dapat menjelaskan peristiwa baru dengan menggunakan konsep Hukum Coulomb yang telah dimiliki seperti menuturkan, menjelaskan dan menerangkan. 6) Merencanakan penelitian sederhana berupa percobaan Hukum Coulomb untuk menguji kebenaran hipotesis. 7) Mengkomunikasikan hasil kegiatan pada orang lain dengan diskusi untuk mengkomunikasikan proses dan hasil penelitian kepada berbagai pihak yang berkepentingan baik dalam bentuk kata-kata, grafik, bagan maupun tabel secara lisan atau tertulis. 3. Penutup. Setelah melaksanakan proses belajar tersebut, hendaknya guru: 1) Mengkaji ulang kegiatan yang telah dilaksanakan serta merumuskan hasil yang telah diperolehnya. 2) Mengadakan tes akhir. 3) Memberikan tugas-tugas lain.

Semua kelompok telah selesai membuat laporan diskusi maka wakil dari kelompok mempresentasikan hasil kerja diskusi. Setelah semua kelompok mempersentasikan hasil diskusinya guru memberikan waktu untuk bertanya tentang hal-hal yang belum difahami.

Penelitian pada siklus I mengharuskan ada peningkatan dalam hal kedisiplinan siswa dalam memasuki ruangan sehingga dalam proses belajar pembelajaran terjadi peningkatan aktivitas siswa. Guru dan observer mengawali pembelajaran dengan masuk ke dalam kelas, guru duduk di depan kelas dan observer di bangku paling belakang dari siswa namun tetap dapat memantau aktifitas guru dan siswa. Penelitian pada siklus ke II ini mengalami kemajuan yaitu dari tingkat kedisiplinan siswa yang mulanya terdapat beberapa orang siswa yang datang terlambat, pada penelitian siklus II ini tidak ada siswa yang datang terlambat hanya ada seorang siswa yang mendapat tugas dari kepala sekolah sehingga masuk terlambat. Guru mengucapkan salam pembukaan pelajaran dan mengabsen siswa, siswa yang namanya dipanggil menjawab hadir, sesekali siswa yang namanya tidak dipanggil juga ikut memberikan jawaban hadir.

Pengamatan siklus II dilakukan oleh observer, yang dimulai dari awal pembelajaran sampai akhir pembelajaran, berikut ini hasil pengamatan siklus II. Persiapan pembelajaran yang dilakukan oleh guru diamati oleh observer didapatkan hasil bahwa persiapan pembelajaran guru pada siklus II yaitu $96,3 \%$. Aktivitas pembelajaran yang dilakukan oleh guru pada siklus II diamati oleh observer didapatkan hasil bahwa aktivitas guru saat pembelajaran pada siklus II yaitu 98\%. Aktivitas siswa pada saat kegiatan pembelajaran yang dilakukan pada siklus II diamati oleh observer didapatkan hasil bahwa aktivitas siswa saat pembelajaran pada siklus II yaitu mencapai skor rata-rata 9,1 dengan kriteria sangat baik.

Tes penguasaan materi peserta didik pada sub konsep Hukum Coulomb terdari dari soal berbentuk essay. Berdasarkan hasil tes diketahui dari 27 siswa yang mengikuti tes terdapat 26 siswa yang nilainya sudah mencapai KKM dengan persentase sebesar $96,3 \%$ dan 1 siswa nilainya belum mencapai KKM dengan persentase sebesar 0,37\%.

Adapun keberhasilan yang telah dicapai dalam pembelajaran siklus II adalah sebagai berikut : 1) Persiapan guru sudah sangat baik. 2) Aktifitas guru sudah sangat baik. 3) Aktifitas siswa sudah sangta baik, dan 4) Hasil belajar siswa sudah mencapai target yaitu sudah mencapai ketentuan ketuntasan secara klasikal. Adapun kelemahan-kelemahan pada siklus II adalah sebagai berikut : 1) Terdapat 26 siswa yang belum tuntas dalam mengikuti pembelajaran. 2) Waktu yang tersedia telah digunakan secara efesien.

Hasil refleksi pada pembelajaran pra siklus sampai siklus II menunjukkan aktivitas dan hasil siswa telah mengalami peningkatan. Semua rangkaian pembelajaran telah dilakukan dan diamati, dan semua aspek yang dinilai telah diolah dan didapati bahwa pembelajaran telah mengalami 
perbaikan. Perbaikan prestasi baik berupa aktivitas dan penguasaan materi, dengan demikian penelitian yang dilakukan dirasa telah cukup sampai di sini dan tidak perlu di lanjutkan ke siklus selanjutnya. Hal ini dengan tercapainya indaikator ketercapaian dalam penelitian tindakan kelas ini. Berikut ini tabel pencapai peningkatan hasil belajar dari pra siklus sampai siklus II.

Tabel 1. Hasil Observasi Persiapan Guru dari Pra Siklus sampai Siklus II

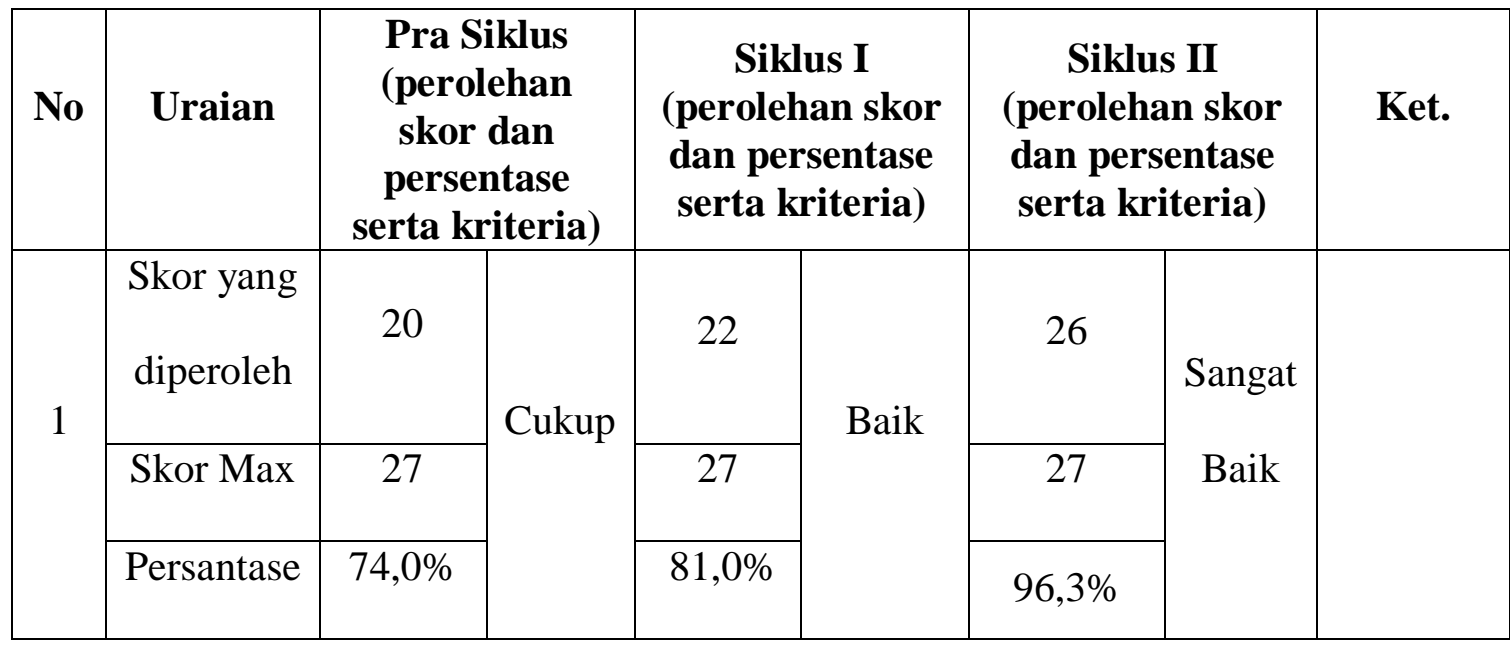

Berdasarkan tabel 1. hasil observasi persiapan guru sebelum kegiatan sudah mengalami peningkatan. Persiapan guru sebelum pembelajaran dari pra siklus ke siklus I mengalami peningkatan sebesar $7,0 \%$ dan dari siklus I ke siklus II mengalami peningkatan sebesar $15,3 \%$. Dengan demikian pencapaian persentase untuk persiapan guru dalam pembelajaran dari pra siklus hingga ke siklus II dapat peneliti katakan bahwa peningkatan sudah signifikan. Berikut adalah tabel hasil observasi aktifitas guru.

Tabel 2. Hasil Observasi Aktivitas Guru

\begin{tabular}{|c|c|c|c|c|c|c|c|c|}
\hline \multirow{3}{*}{$\begin{array}{r}\text { No } \\
\\
1 \\
1\end{array}$} & \multirow{2}{*}{$\begin{array}{c}\text { Uraian } \\
\text { Skor yang } \\
\text { diperoleh }\end{array}$} & \multicolumn{2}{|c|}{$\begin{array}{c}\text { Pra Siklus } \\
\text { (perolehan } \\
\text { skor dan } \\
\text { persentase } \\
\text { serta kriteria) }\end{array}$} & \multicolumn{2}{|c|}{$\begin{array}{c}\text { Siklus I } \\
\text { (perolehan skor } \\
\text { dan persentase } \\
\text { serta kriteria) }\end{array}$} & \multicolumn{2}{|c|}{$\begin{array}{c}\text { Siklus II } \\
\text { (perolehan skor } \\
\text { dan persentase } \\
\text { serta kriteria) }\end{array}$} & Ket. \\
\hline & & 24 & \multirow{3}{*}{ Cukup } & 35 & \multirow{3}{*}{ Baik } & 42 & \multirow{3}{*}{$\begin{array}{c}\text { Sangat } \\
\text { Baik }\end{array}$} & \\
\hline & Skor Max & 48 & & 48 & & 48 & & \\
\hline & Persantase & $50,0 \%$ & & $77,1 \%$ & & $98,0 \%$ & & \\
\hline
\end{tabular}

Berdasarkan tabel 2. hasil observasi aktivitas guru dalam pembelajaran sudah mengalami peningkatan. Aktivitas guru dalam pembelajaran dari pra siklus ke siklus I sudah mengalami peningkatan sebesar $27,1 \%$ dan dari siklus I ke siklus II mengalami peningkatan sebesar $20,9 \%$. Dengan pencapaian persentase tersebut untuk aktivitas guru dalam pembelajaran dari pra siklus samapai pada siklus II maka peneliti dapat mengatakan bahwa aktivitas guru dalam pembelajaran sudah mengalami peningkatan yang signifikan. Berikut ini tabel tentang hasil belajar IPA pada konsep Listrik Statis. 
Tabel 3. Hasil Belajar Siswa

\begin{tabular}{|c|l|c|c|c|c|c|c|c|}
\hline \multirow{2}{*}{ No } & Jumlah Siswa & \multicolumn{2}{|c|}{ Pra Siklus } & \multicolumn{2}{|c|}{ Siklus I } & \multicolumn{2}{|c|}{ Siklus II } & \multirow{2}{*}{ Ket. } \\
\hline \multirow{2}{*}{1} & Peserta Tes & 27 & $100 \%$ & 27 & $100 \%$ & 27 & $100 \%$ & \\
\cline { 2 - 8 } & Tuntas & 18 & $67,0 \%$ & 21 & $77,8 \%$ & 26 & $96,3 \%$ & \\
\cline { 2 - 8 } & Tidak Tuntas & 9 & $33,0 \%$ & 6 & $22,2 \%$ & 1 & $3,7 \%$ & \\
\hline
\end{tabular}

Berdasarkan tabel 3. hasil belajar siswa dalam pembelajaran mengalami peningkatan yang signifikan. Hasil belajar siswa dalam pembelajaran dari pra siklus ke siklus I mengalami peningkatan sebesar $10,8 \%$, sedangkan dari siklus I ke siklus II mengalami peningkatan sebesar $22,22 \%$. Dengan pencapaian persentase ketuntasan hasil belajar siswa $96,3 \%$ pada siklus II maka peneliti berpendapat bahwa siklus pembelajaran tidak perlu dilanjutkan ke siklus berikutnya.

Hasil observasi aktifitas siswa mulai dari pra siklus sampai siklus II yaitu :

Tabel 4. Hasil Observasi Aktivitas Siswa

\begin{tabular}{|c|l|c|c|c|c|c|c|c|}
\hline \multirow{2}{*}{ No } & \multicolumn{1}{|c|}{ Kriteria } & \multicolumn{2}{|c|}{$\begin{array}{c}\text { Pra Siklus } \\
\text { (jumlah siswa } \\
\text { \& Persentase) }\end{array}$} & \multicolumn{2}{|c|}{$\begin{array}{c}\text { Siklus I } \\
\text { (jumlah } \\
\text { siswa \& } \\
\text { Persentase) }\end{array}$} & \multicolumn{2}{|c|}{$\begin{array}{c}\text { Siklus II } \\
\text { (jumlah } \\
\text { siswa \& } \\
\text { Persentase) }\end{array}$} & \multirow{2}{*}{ Ket. } \\
\hline \multirow{3}{*}{1} & Sangat Baik & 0 & $0,00 \%$ & 3 & $11,1 \%$ & 19 & $70.40 \%$ & \\
\cline { 2 - 8 } & Baik & 9 & $33,33 \%$ & 13 & $48,1 \%$ & 8 & $29,60 \%$ & \\
\cline { 2 - 9 } & Cukup & 18 & $66,67 \%$ & 11 & $40,70 \%$ & 0 & $0,00 \%$ & \\
\hline
\end{tabular}

Tabel 4. menunjukkan bahwa hasil observasi aktivitas siswa dalam pembelajaran mengalami peningkatan yang signifikan. Aktivitas siswa dalam pembelajaran dari pra siklus ke siklus I mengalami peningkatan mencapai kriteria baik sebesar $11,11 \%$. Sedangkan dari siklus I ke siklus II mengalami aktivitas siswa mengalami peningkatan yang signifikan hingga mencapai kriteria sangat baik sebesar $70,40 \%$. Dengan pencapaian persentase $70,40 \%$ untuk aktivitas siswa dalam pembelajaran pada siklus II maka peneliti berpendapat bahwa siklus pembelajaran tidak perlu dilanjutkan ke siklus berikutnya.

Semua kegiatan penelitian di mulai dari pra siklus hingga ke siklus II dalam proses pembelajaran telah dilakukan dan diamati, dan semua aspek yang dinilai telah diolah dan dianalisa. Pembelajaran IPA dengan menerapkan pendekatan pembelajaran keterampilan proses di kelas IX-a SMP $\mathrm{N} 3$ Belitang Madang Raya tahun pembelajaran 2016/2017 telah mengalami peningkatan. Peningkatan yang diperoleh berupa persiapan guru, aktivitas guru, aktivitas siswa dan penguasaan materi oleh siswa. Dengan demikian penelitian yang dilakukan telah mencapai pada tujuan penelitian dan tidak perlu di lanjutkan ke siklus selanjutnya.

\section{PENUTUP}

Penelitian tindakan kelas (PTK) dalam upaya peningkatan hasil belajar IPA Fisika melalui penerapan pendekatan keterampilan proses pada materi pembelajaran Listrik Statis di kelas IX-a SMP Negeri 3 Belitang Madang Raya tahun pembelajaran 2016/2017, yang telah di laksanakan dengan di awali pra siklus kemudian dilanjutkan dua siklus, pada masing-masing siklus terdapat pengamatan dan penilaian untuk persiapan pembelajaran, aktivitas guru dan siswa serta hasil belajar siswa. Hasil 
penelitian tindakan kelas ini dapat disimpulkan sebagai berikut : 1) Aktivitas siswa dalam pembelajaran dari pra siklus ke siklus I mengalami peningkatan hingga mencapai kriteria sangat baik sebesar $11,11 \%$. Sedangkan dari siklus I ke siklus II mengalami aktivitas siswa mengalami peningkatan yang signifikan hingga mencapai kriteria sangat baik sebesar 70,4\%. 2) Hasil belajar siswa dalam pembelajaran dari pra siklus ke siklus I mengalami peningkatan sebesar 10,8\%, sedangkan dari siklus I ke siklus II mengalami peningkatan sebesar $22,22 \%$. 3) Persiapan guru sebelum pembelajaran dari pra siklus ke siklus I mengalami peningkatan sebesar $7,0 \%$ dan dari siklus I ke siklus II mengalami peningkatan sebesar $15,3 \%$. 4) Aktivitas guru dalam pembelajaran dari pra siklus ke siklus I sudah mengalami peningkatan sebesar $27,1 \%$ dan dari siklus I ke siklus II mengalami peningkatan sebesar $20,9 \%$.

Berdasarkan hasil penelitian yang telah dilaksanakan, peneliti dapat memberikan saran yaitu guru yang akan menyampaikan materi pembelajaran Listrik Statis di kelas IX disarankan dapat menggunakan pendekatan pembelajaran keterampilan proses, hal ini didasari dari hasil penggunaan pendekatan pembelajaran keterampilan proses yang dapat meningkatkan prestasi belajar siswa. Guru yang akan menggunakan pendekatan pembelajaran keterampilan proses sebaiknya harus tetap mengikuti langkah-langkah penggunaan pendekatan pembelajaran tersebut dan pokok-pokok materi pembelajaran yang dipilih harus sesuai dengan karakteristik pendekatan pembelajaran keterampilan proses. Penelitian lanjutan yang menggunakan pendekatan pembelajaran keterampilan proses untuk meneliti aktivitas belajar siswa hendaknya selalu menggunakan pedoman penskoran yang jelas dan mengikuti prosedur dalam pengisian lembar observasi. Penggunaan pendekatan pembelajaran keterampilan proses atau pendekatan pembelajaran lainnya sebaiknya dipergunakan pada materi pembelajaran yang sesuai dengan tujuan pembelajarannya.

Penutup berisi simpulan dan saran. Simpulan memuat jawaban atas pertanyaan penelitian. Saran-saran mengacu pada hasil penelitian dan berupa tindakan praktis, sebutkan untuk siapa dan untuk apa saran ditujukan. Bagian penutup ditulis dalam bentuk essay, bukan dalam bentuk numerikal.

\section{DAFTAR PUSTAKA}

Arikunto, S. (2015). Dasar-dasar evaluasi pendidikan: Edisi ke dua. Jakarta: Bumi. Aksara

Firdaus, T., \& Sinensis, A. R. (2017). Keterampilan Dasar Kinerja IImiah Pada Mahasiswa Calon Guru Fisika. Jurnal Pendidikan Fisika, 5(2), 102-110.

Hamalik, O. (2010). Belajar dan Faktor-faktor yang Mempengaruhinya. Jakarta: Rineka Cipta.

Hopkins, D. (2014). A teacher's guide to classroom research. McGraw-Hill Education (UK).

Rohani, A., \& Ahmadi, A. (2004). Pengelolaan Pembelajaran. Jakarta: Rineka Cipta.

Undang-undang Republik Indonesia No.20 th 2003. Tentang Sistem Pendidikan Nasional. Jakarta:Departemen Pendidikan Nasional Republik Indonesia 